\title{
Effect of Different Temperatures on Some Biological Aspects of the Predaceous Mite, Agistemus exsertus Gonzalez
}

\author{
Dalia, A. Waked \\ Plant Protec. Res. Inst.. Agric. Res. Center. Dokki. Giza. Fgypt.
}

\begin{abstract}
Life cycle of $\mathrm{A}$. exsertus female differed according to temperature degree: the shortest period was at $30^{\circ} \mathrm{C}, 8.23$ days, while the longest at $20{ }^{\circ} \mathrm{C}, 12.02$ days. The developmental rate ranged from $68.14 \%$ at $20{ }^{\circ} \mathrm{C}$ to $73.04 \%$ at $30{ }^{\circ} \mathrm{C}$ for female. Survival female's immatures \% was also affected with temperature being $73.45,80.24$ and $83.61 \%$ at 20,25 and $30{ }^{\circ} \mathrm{C}$. respectively. The total amount of consumed preys/predator different developmental stages and sex increased with increased temperature from 20 to $30^{\circ} \mathrm{C}$. The total average number of $T$. urticae fed by predator immatures was 17.23 , 14.76 and 10.71 preys at 30.25 and $20^{\circ} \mathrm{C}$. Also, female predator consumed greater number of prey individuals at high temperature, 78.34 preys at $30^{\circ} \mathrm{C}$, decreased to 65.25 preys at $25{ }^{\circ} \mathrm{C}$ but the rate of consumption was less at low temperature 50.00 preys at $20^{\circ} \mathrm{C}$. The effect of temperature on life table parameters was determined. Net reproductive rate $\left(\mathrm{R}_{0}\right)$ differed according to temperature as this value increased with temperature increase. Thus, these values averaged $11.21,15.04$ and 21.57 times for 20,25 and $30{ }^{\circ} \mathrm{C}$. The intrinsic rate of increase $\left(\mathrm{r}_{\mathrm{m}}\right)$ was $0.10,0.13$ and 0.15 individuals/female/day for the above same order. The mean generation time ( $\mathrm{T}$ ) decreased when the temperature increased.
\end{abstract}

Key words: Agistemus exsertus; Temperatures; Biological aspects.

\section{INTRODUCTION}

Family Stigmaeidae is one of the most important predators of phytophagous mites, especially Agistemus exsertus Gonzalez which well known as an efficient predator (Rai \& Singh 1999 and Ahmed \& Ibrahim 2001). Many authors recorded this stigmaeiid mite, as an aerial predator, occurring all over the year on several fruit trees, field crops, vegetables and ornamentals (Gupta et al., 1971; Soliman 1987; El-Duweini et al.; 2003 and Azouz, 2005). Its population increases during spring, summer and autumn. It is usually found associated with colonies of tetranychid and tenuipalpid mites and scale insects.

$A$. exsertus was able to survive and reproduce on Tetranychus urticae eggs and immatures of which eggs were more favorable (Hanna et al., 1984 and Shoeib, 1996). Abou-Awad and El-Sawi (1993) studied the effect of temperature on $A$. exsertus, reared on $T$. urticae eggs. The aim of the present study was to evaluate the effects of different temperatures on its biological aspects and life table parameters.

\section{MATERIALS AND METHODS}

\section{Effect of tempe rature on predaceous mite:}

Agistemus exsertus newly deposited eggs were transferred singly to leaf mulberry discs, each of one inch in diameter as rearing arenas in Petri-dishes on water saturated cotton and kept on 30,25 and $20^{\circ} \mathrm{C}$ until hatching and incubation period was recorded. Each newly hatched larva (25 replicates) was supplied with sufficient known number of the prey ( $T$. urticae immature). All larvae were reared individually under different temperatures, 30, 25 and $20{ }^{\circ} \mathrm{C}$ till reached adulthood. Before the final molt of the female, one adult male was introduced to the replicate for mating and removed after one day. Experiment was observed twice a day. The number of laid eggs was counted daily as well as consumption rate until female died. Longevity and consumption of adult male was also recorded. Three different temperatures $\left(20,25\right.$ and $\left.30^{\circ} \mathrm{C}\right)$ were tested.

During developmental period, mortalities of different reared females' predator stages were recorded. Eggs of resultant females were collected daily from each female and sex ratio of the progeny was determined. Life table parameters were estimated using the life 48 computer program Abou-Setta et al. (1986).

Data were subjected to statistical analysis using one way analysis of variance, ANOVA Duncan (1955).

\section{RESULTS AND DISCUSSION}

\section{Influe nce of temperature on developmental time:}

The average duration of every stage of $A$. exsertus females and males at each temperature degree were presented in table (1). E incubation period decreased with temperature increase $\left(20-30{ }^{\circ} \mathrm{C}\right)$, averaging 2.82 , 3.23 and 3.90 days at 20,25 and $30^{\circ} \mathrm{C}$, respectively. Total immatures durated 8.12,5.94 and 5.41 days at 30,25 and $20^{\circ} \mathrm{C}$, respectively. The male followed similar trend, but having shorter periods. These findings were previously mentioned by Ferla and Moreas (2003). In accordance with results obtained, 
Table (1): Agistemus exsertus. life çcle and immatures survival at different temperatures

\begin{tabular}{|c|c|c|c|c|c|c|c|c|c|}
\hline \multirow{2}{*}{$\begin{array}{l}\text { Temp. } \\
\text { ("C) }\end{array}$} & \multirow[b]{2}{*}{ Sex } & \multicolumn{5}{|c|}{ Development duration in days (mean \pm S.E) } & \multirow{2}{*}{$\begin{array}{l}\text { Life } \\
\text { cycle }\end{array}$} & \multirow{2}{*}{$\begin{array}{c}\text { Survival } \\
\%\end{array}$} & \multirow[b]{2}{*}{$\begin{array}{c}\text { Development } \\
\%\end{array}$} \\
\hline & & Egg & I ama & $\begin{array}{l}\text { Proto- } \\
\text { nymph }\end{array}$ & $\begin{array}{l}\text { Deuto- } \\
\text { nymph }\end{array}$ & $\begin{array}{c}\text { Total } \\
\text { immature }\end{array}$ & & & \\
\hline \multirow{2}{*}{30} & 9 & $2.82 \pm 0.04$ & $1.43 \pm 0.30$ & $1.51 \pm 0.62$ & $2.47 \pm 1.23$ & $5.41 \pm 0.04$ & $8.23 \pm 0.02$ & $83.61 \pm 2.56$ & $73.04 \pm 2.02$ \\
\hline & 3 & $2.79 \pm 0.02$ & $1.44 \pm 0.26$ & $1.30 \pm 0.73$ & $2.21 \pm 1.62$ & $4.95 \pm 0.07$ & $7.74 \pm 0.05$ & $79.26 \pm 2.41$ & $72.00+1.97$ \\
\hline \multirow{2}{*}{25} & 용 & $3.23 \pm 0.11$ & $1.63 \pm 0.41$ & $1.70 \pm 0.56$ & $2.61 \pm 1.59$ & $5.94 \pm 0.02$ & $9.17 \pm 0.03$ & $80.24 \pm 2.72$ & $75.25 \pm 1.86$ \\
\hline & 3 & $2.90 \pm 0.13$ & $1.50 \pm 0.60$ & $1.65 \pm 0.38$ & $2.57 \pm 1.21$ & $5.72 \pm 0.11$ & $8.62 \pm 0.01$ & $76.00+1.98$ & $73.48 \pm 1.59$ \\
\hline \multirow{2}{*}{20} & 9 & $3.90 \pm 0.07$ & $2.32 \pm 0.82$ & $2.81 \pm 0.94$ & $2.99+1.57$ & $8.12+0.15$ & $12.02+0.07$ & $73.45 \pm 1.64$ & $68.14 \pm 1.47$ \\
\hline & 3 & $3.70 \pm 0.05$ & $2.31 \pm 0.93$ & $2.45 \pm 0.87$ & $2.65 \pm 1.43$ & $7.41 \pm 0.16$ & $11.11 \pm 0.04$ & $67.58 \pm 1.59$ & $62.53 \pm 1.32$ \\
\hline
\end{tabular}

Table (2): Food consumption of Agistemus exsertus fed on T. urticae at different temperatures

\begin{tabular}{cccccc}
\hline Temp. $\left({ }^{\circ} \mathrm{C}\right)$ & Sex & Total immatures & Oviposition period & Adult longevity & Life span \\
\hline \multirow{2}{*}{30} & $q$ & $17.23 \pm 0.09$ & $52.12 \pm 1.14^{\mathrm{a}}$ & $78.34 \pm 1.76^{\mathrm{a}}$ & $95.57 \pm 2.01$ \\
\cline { 2 - 6 } & \multirow{2}{*}{25} & $15.51 \pm 0.04$ & - & $59.07 \pm 1.34$ & $74.58 \pm 1.68$ \\
\hline \multirow{2}{*}{25} & $f$ & $14.76 \pm 0.11$ & $44.41 \pm 1.18^{\mathrm{b}}$ & $65.25 \pm 1.85^{\mathrm{b}}$ & $80.01 \pm 1.32$ \\
\cline { 2 - 6 } & 0 & $13.83 \pm 0.16$ & - & $52.67 \pm 1.13$ & $66.50 \pm 1.43$ \\
\hline \multirow{2}{*}{20} & 0 & $10.71 \pm 0.13$ & $29.47 \pm 0.96^{\mathrm{c}}$ & $50.00 \pm 1.20^{\mathrm{c}}$ & $60.71 \pm 1.17$ \\
\cline { 2 - 6 } & \multirow{3}{*}{} & $7.00 \pm 0.02$ & - & $38.24 \pm 1.07$ & $45.24 \pm 1.05$ \\
\hline
\end{tabular}

Means in columns followed by the same letter are not significantly different at $p \leq 5 \% \pm$ standard error

Table (3): Life table parameters of Agistemus exsertus at different temperatures

\begin{tabular}{|c|c|c|c|c|c|c|c|c|}
\hline Temp. $\left({ }^{\circ} \mathrm{C}\right)$ & Sex & Longevity (days) & Fecundity & Sex ratio $9 \%$ & $\mathrm{R}_{0}$ & $\mathrm{~T}$ & $r_{m}$ & $\lambda$ \\
\hline \multirow{2}{*}{30} & 오 & $12.13 \pm 0.04^{\mathrm{c}}$ & $43.78 \pm 1.82^{\mathrm{a}}$ & $70.25 \pm 1.87^{\mathrm{a}}$ & 21.57 & 10.61 & 0.15 & 1.21 \\
\hline & $d$ & $11.56 \pm 0.02$ & - & - & - & - & - & - \\
\hline \multirow{2}{*}{25} & 요 & $17.02 \pm 0.10^{\mathrm{b}}$ & $40.50 \pm 1.41^{\mathrm{a}}$ & $69.08 \pm 1.43^{\mathrm{a}}$ & 15.04 & 11.83 & 0.13 & 1.00 \\
\hline & 3 & $12.98 \pm 0.24$ & - & - & - & - & - & - \\
\hline \multirow{2}{*}{20} & 9 & $20.34 \pm 0.28^{a}$ & $28.47 \pm 0.09^{b}$ & $67.46 \pm 1.15^{\mathrm{a}}$ & 11.21 & 14.05 & 0.10 & 0.77 \\
\hline & $\hat{\sigma}$ & $17.68 \pm 0.22$ & - & - & - & - & - & - \\
\hline
\end{tabular}

Means in columns followed by the same letter are not significantly different at $p \leq 5 \% \pm$ standard error.

egg incubation total immatures and life cycle of $A$. exsertus differed according to temperature degree. The shortest period was at $30{ }^{\circ} \mathrm{C}$ ( 8.23 days); while the longest was at $20{ }^{\circ} \mathrm{C}(12.02$ days $)$. The developmental rate ranged from $68.14 \%$ at $20{ }^{\circ} \mathrm{C}$ and $73.04 \%$ at $30^{\circ} \mathrm{C}$ for female. For female survival immature $\%$ affected with different temperature these values were $73.45,80.24$ and $83.61 \%$ at 20,25 and $30{ }^{\circ} \mathrm{C}$, respectively. These results are agreement with Abo-Taka et al. (2009) who studied the effect of the four temperature degrees $15,20,25$ and $30^{\circ} \mathrm{C}$ on different stages of the predaceous mite, A. exsertus. Life cycle was very low at $30{ }^{\circ} \mathrm{C}$; while it increased at $15^{\circ} \mathrm{C}$.

\section{Feeding capacity:}

Feeding capacity of $A$. exsertus on $T$. urticae was affected by temperature (Table 2) with significant differences at three different temperatures.

The total amount of consumed prey/predator different developmental stages and sex increased as temperature increased from 20 to $30^{\circ} \mathrm{C}$. The total average number of $T$. urticae fed by predator immatures was $17.23,14.76$ and 10.71 preys at 30,25 and $20^{\circ} \mathrm{C}$. Female predator consumed greater number of preys at high temperature $\left(78.34\right.$ preys at $30^{\circ} \mathrm{C}$ and 65.25 preys at $25^{\circ} \mathrm{C}$ ). Male followed similar trend as that of female, but in smaller numbers. Also, Yue and Childers (1994) who reared A. exsertus on citrus spider mite $P$. citri in Florida at 15, 20, 25, 30 and $35{ }^{\circ} \mathrm{C}$ obtained best results with regard prey consumption and egg production at $25^{\circ} \mathrm{C}$. Also, Inoue and Tanaka (1983) showed that Agistemis terminalis female preyed on 1, 2.4 and 3.4 Panonychus citri / day when kept at 20,25 and $30^{\circ} \mathrm{C}$, respectively.

\section{Adult female longevity, fecundity and life table parameters:}

Temperature negatively affected the duration of $A$. exsertus adult, Table (3). Adult female longevity decreased with increasing temperature from 20 to $30{ }^{\circ} \mathrm{C}$.

Average female lived for 20.34, 17.02 and 12.13 days at 20,25 and $30^{\circ} \mathrm{C}$, respectively. Concerning female fecundity, temperature had a significant effect on egg total egg production; the greatest number of eggs (43.78 eggs) was deposited by female at $30^{\circ} \mathrm{C}$. 
Adult male followed similar trend as that of female longevity but having shorter periods. The effect of temperature on life table parameters was determined. Net reproductive rate $\left(R_{0}\right)$ differed according to temperature as this values increased with temperature increase. Thus, these values averaged 11.21, 15.04 and 21.57 times for 20,25 and $30^{\circ} \mathrm{C}$. The intrinsic rate of increase $\left(\mathrm{r}_{\mathrm{m}}\right)$ was $0.10,0.13$ and 0.15 individual/female/day for the above same order. The mean generation time ( $\mathrm{T}$ ) decreased when the temperature increased. Similar results were also obtained by Yue and Childers (1994) who investigated the effects of temperature on development and reproduction of Agistemus exsertus. The mite was provided with eggs of Panonychus ulmi as a food source. At $15,20,25,30$ and $35^{\circ} \mathrm{C}$, the mean length of a generation was $35.9,18.1,14.5,11.4$ and 12.6 days, respectively. A female produced an average $66.0,69.0,46.5,25.5$ and 18.8 eggs, respectively. The attack rate of females on eggs was less at 20 and $30^{\circ} \mathrm{C}$ than at 10 or $40^{\circ} \mathrm{C}$. Also, AbouAwad and Elsawi (1993) found that at $27^{\circ} \mathrm{C}, \mathrm{r}_{\mathrm{m}}$ value of $A$. exsertus fed on $T$. urticae was 0.15 . El- Laithy (1998) found that expected rate of increase $(\lambda)$ of $A$. exsertus was 1.24 when kept at $27^{\circ} \mathrm{C}$.

\section{REFERENCES}

Abou-Awad, B. A. and El-Sawi, S. A. 1993. Biology and life table of the predacious mite, Agistemus exsertus Gonz. (Acari: stigmaeidae). Anz. Schadling. Pflanzenschutz. Umwelt., 66(5): 101-103.

Abou-Setta, M. A.; Sorrell, R. W. and Childers, C. C. 1986. Life 48: A basic computer program to calculate life table parameters for an insect or mite species. Fla. Entomol., 69: 690-697.

Abo-Taka, S. M.; Sweelam, M. E.; Hussain, A. M. and Wallash, E. M. 2009. Effect of different temperature on some biological characters of predator, Agistemus exsertus. Nile Dalta Conf. on Export Crops, Fac. of Agric., Minufiya Univ.

Amira, A. A. M. Shoeib.1996. Biological and ecological studies on some predaceous mites. $\mathrm{Ph}$. D. Thesis, Fac. Agric., Cairo, Univ., 224pp.

Azouz, H. A. A. 2005. Ecological and biological studies on some mites associated with cotton and some field crops in Beni Suef governorate, Ph. D. Thesis, Fac. Agric. Al-Azhar Univ., 185pp.

Duncan, D. B. 1955.Multiple range and multiple F. tests.Biometrics. 11:1- 41
El-Duweini. F. K.; Gerges, M. F.; Sourial, L. S. and Henien. S. M. 2003. Survey of insects and mites associated with soybean and maize in various intercropping systems. J. Agric. Sci. Mansoura, Univ.. 28(2): 1439-1446.

El-Laithy, A. Y. M. 1998. Laboratory studies on growth parameters of three predatory mites associated with eriophyid mites in olive nurseries. Zeitschrift fur Pflanzenkrankheiten und Pflanzenschutz, 105(1):78-83.

Ferla, N. J. and Moraes, G. J. de. 2003. Biology of Agistemus floridanus Gonzalez (Acari: Stigmaeidae). Revista Brasileira de Zoologia, 20 (2): 261-264.

Gupta, S. K.; Dhooria, M. S. and Sidhu, A. S. 1971.A note on predators of citrus mites in Punjab. Science and Culture, 37: 484pp.

Hanna, M. A.; Shereef, G. M. and Megali, M. K. 1984. Effect of food type on longevity and fecundity of the predatory mite, Agistemus exsertus Gonzalez (Acari: Prostigmata) with first description of its prelarva. Bull. Soc. Ent. Egypte, 63: 57-62.

Inoue, K. and Tanaka, M. 1983. Biological characteristics of Agistemus terminalis (Quayle) (Acarina:Stigmaeidae) as a predator of citrus red mite, Panonychus citri (McGregor). Japanese J. Appli.Entomol. Zool., 27: 280-288.

Rai, S. N. and Singh, J. 1999. Biology of Agistemus industani (Acari: Stigmaeidae) an efficient predator of Tetranychus ludni on mulberry. All India coordinated research project on agricultural acarology, department of entomology. Instit. Agricul. Sci. Banaras Hindu Univ. Varanasi, 221-500.

Soliman, S. M. 1987. Morphological and biological studies on some predaceous mites of suborder: Actinedida. M. Sc. Thesis, Fac. Agric. Al-Azhar Univ., 75 pp.

Wafaa, O. G. Ahmed and Ibrahim, A. M. A. 2001. Feeding capacity, reproduction and competition between the two predators, Agistemus exsertus Gonzalez (Prostigmata: Stigmaeidae) and Orius laevigataus (Fieber) (Hemiptera: Anthocoridae) associating with the spider mite, Tetranychus urticae Koch. J. Agric. Sci., Mansoura Univ., 26(9): 5783-5790.

Yue, B. and Childers, C. C. 1994. Effects of temperature on life table parameters of Agistemus exsertus Gonzalez (Acari: Stigmaeidae) and its attack rate on Panonychus citri eggs. Inter. J. Acarol., 20(2): 109-113. 